\title{
Impact of hydrodynamics on development and morphology of intertidal seagrasses in the Wadden Sea
}

\author{
Anja Schanz*, Harald Asmus \\ Alfred Wegener Institute for Polar and Marine Research, Wadden Sea Station Sylt, Hafenstrasse 43, 25992 List, Germany
}

\begin{abstract}
Field surveys and in situ experiments were conducted to determine the impact of hydrodynamics (in particular tidal currents) on the development and structure of intertidal seagrass beds. Field observations in the Sylt-Rømø Bight (German Wadden Sea, North Sea) from 1997 to 1999 revealed dense seagrass beds with a high biomass in sheltered areas, whereas at exposed sites seagrass beds occurred only sparsely with a comparatively low biomass. In addition, the shoot length and leaf length were distinctly higher at sheltered sites than in exposed beds. Cross transplantation experiments and enclosure experiments between sheltered and exposed seagrass sites showed that the density as well as the shoot morphology (leaf number per shoot, shoot length, leaf length and leaf width) were drastically reduced after transplantation into an exposed bed, and were even lower than seagrass values of the adjacent exposed seagrasses after $6 \mathrm{wk}$. In contrast, the seagrass density as well as the length of shoots and leaves increased distinctly after transplantation into a sheltered seagrass bed. By means of an in situ 'three-current flume', experimentally modifying current flow at the same site, it was shown that increasing tidal current velocities resulted in decreased densities and length values in seagrass shoots, despite growing under the same habitat conditions. These results suggest that strong hydrodynamics directly affect the development and architecture of Zostera noltii beds by reducing seagrass density and shoot morphology, as well as the extent of seagrass beds. Since changes in environmental conditions are ongoing (e.g. higher storm frequency, sea level rise in combination with man-made protective structures, such as dikes and dams), it is suspected that increasing hydrodynamics might contribute to losses in intertidal seagrass beds.
\end{abstract}

KEY WORDS: Hydrodynamics $\cdot$ Seagrass beds $\cdot$ Zostera noltii $\cdot$ Currents $\cdot$ Pattern $\cdot$ Development · Growth $\cdot$ Wadden Sea

\section{INTRODUCTION}

Seagrass beds occur in coastal waters all over the world, and are linked to multiple ecosystem functions characterised by high productivity and biodiversity (e.g. den Hartog 1970, Larkum et al. 1989). Losses of seagrass populations appear to be continuing in many coastal ecosystems, and has been attributed to humaninduced disturbances and climatic changes, e.g. enhanced nutrients and deterioration of light availability (Borum 1985, 1996, Burkholder et al. 1992, 1994, Short \& Burdick 1996), and/or changes in temperature and salinity (Bulthuis 1987, Kamermans et al. 1999, van Katwijk et al. 1999). The effect of hydrodynamics, in particular tidal range, current velocities and wave dynamics, is superimposed on most of these factors, and affects various processes in the seagrass system (Fonseca \& Kenworthy 1987, Worcester 1995, Short \& Neckles 1999). Hydrodynamics can promote the development of seagrass beds, e.g. by mixing the water column, thereby facilitating nutrient uptake and enhancing photosynthesis due to the decreasing thickness of the diffusive boundary layer (Fonseca \& Kenworthy 1987, Koch 1994). In addition, lateral and vertical advection is important for pollination and seed dispersal (Thayer et al. 1984, Orth et al. 1994, Verduin 1996, 
Ackerman 1997). On the other hand, seagrasses are able to reduce current flow, and attenuate wave energy, due to their density and the narrow leaf surface (e.g. Fonseca et al. 1982, Gambi et al. 1990, Fonseca \& Cahalan 1992, Koch 1996, Koch \& Gust 1999, Verduin \& Backhaus 2000), thereby reducing erosion and resuspension of the sediment. However, if an increase in hydrodynamics exceeds a certain threshold that surpasses the existing equilibrium between the seagrass bed and the ambient physical conditions (Fonseca et al. 1983, Fonseca \& Kenworthy 1987), this might trigger deterioration of seagrasses, due to erosion processes that enhance resuspension of sediments, thereby promoting turbidity, and may in some instances cause the complete loss of a seagrass bed (Scoffin 1970, Patriquin 1975).

In the Wadden Sea seagrasses are regularly exposed to strong water movement. Long-term observations showed that hydrodynamics incrementally increased during the last century, due to the construction of dikes and dams, increased fishery, as well as a rise in the sea level (Reise 1989, de Jonge \& de Jong 1992). As a consequence, historical changes in seagrass habitats, as well as the lack of re-establishment of former extensive meadows, might have been triggered by increasing water volume in the tidal channels due to erosion processes (Harlin et al. 1982, de Jonge \& de Jong 1992, Asmus \& Asmus 1998). Recent transplantation and restoration experiments in the Dutch Wadden Sea gave evidence that zonation patterns of Zostera marina in the lower and upper tidal areas might be affected by higher water movement, such as wave dynamics (de Jonge et al. 2000, van Katwijk \& Hermus 2000).

Based on field observations comparing a dense, sheltered seagrass bed and a comparatively sparse seagrass stand exposed to stronger tidal currents and waves, it was hypothesised that higher hydrodynamics may directly alter seagrass bed architecture and may lead to a restricted distribution of Zostera noltii in the Wadden Sea. To demonstrate experimentally whether a difference in water movement influences the growth of $Z$. noltii and how this may impact seagrass bed structure and plant morphology, cross transplantation experiments with and without enclosures between sheltered and exposed seagrass beds were carried out. To quantify the direct impact of modified tidal current velocities on seagrass architecture and development under the same habitat conditions, an in situ 'threecurrent flume' modifying the entire range of current velocities was used.

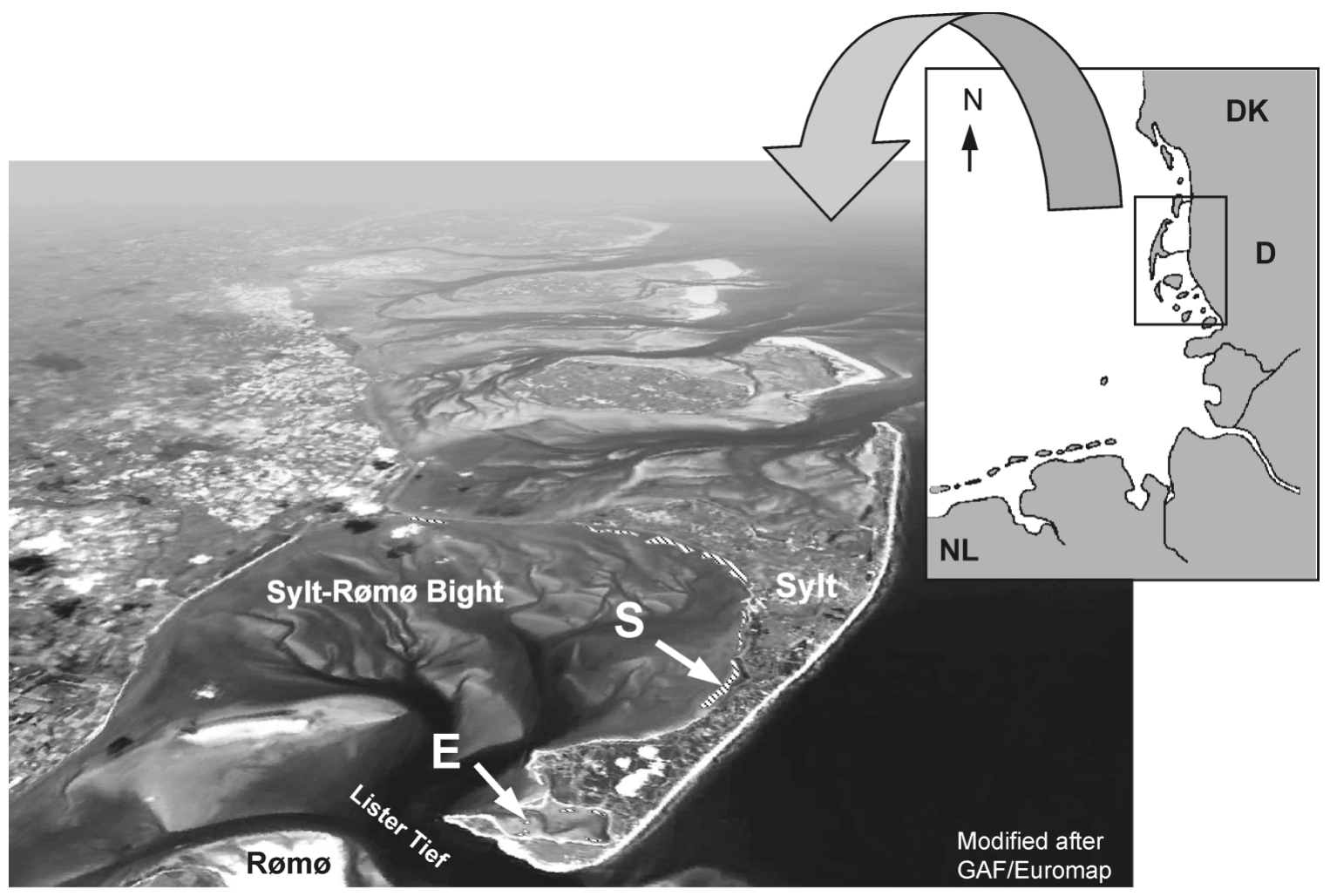

Fig. 1. Location of the study area in the Wadden Sea near the island of Sylt, North Sea, Germany. Distribution of intertidal Zostera noltii beds (hatching) along the eastern coast of Sylt. Arrows indicate the investigated hydrodynamically exposed (E) and sheltered (S) seagrass sites in the Sylt-Rømø Bight. (DK: Denmark; D: Germany; NL: Netherlands) 


\section{MATERIALS AND METHODS}

Study site. The study was conducted within 2 intertidal Zostera noltii beds near the island of Sylt, which is situated in the German part of the North Sea (Fig. 1). The investigated seagrass sites are part of a shallow tidal basin (Sylt-Rømø Bight), where only one connection to the North Sea exists (Fig. 1). Tides are semidiurnal, with a mean tidal range of about $2 \mathrm{~m}$, and salinity varies seasonally between 25 and $32 \%$.

In the Sylt-Rømø Bight, $12 \%$ of the tidal flats is covered by seagrass beds, dominated by Zostera noltii. $Z$. noltii beds grow under different degrees of hydrodynamic exposure, and are emerged for 4 to $6 \mathrm{~h}$ per tidal cycle. Although the exposure of seagrass beds to water dynamics primarily consists of both tidal currents and wind-induced waves, this study primarily considered the effect of currents as the most stable component of water movement for investigations of long-term processes and their effect on seagrass bed development. Wind-induced waves are highly variable, and can only be considered a short-term effect, due to the lack of historical data. Two Z. noltii beds were studied from 1997 to 1999 during their main vegetation periods (Fig. 1): an exposed, sparse $Z$. noltii bed growing on very coarse sand (poorly sorted) close to a deep tidal channel, where initial tidal currents from 0.20 up to $0.33 \mathrm{~m} \mathrm{~s}^{-1}$ were recorded in the centre of the seagrass bed during calm weather (during the first hour of the flood tide from April to September 1999) (Fig. 1, Table 1); and a second, sheltered and more extensive $Z$. noltii bed on coarse sand (well to poorly sorted), which was located deeper in the bight, and therefore was protected by the island from prevailing westerly winds and stronger currents, due to deep tidal gullies. Here initial tidal current velocities of 0.04 up to $0.20 \mathrm{~m} \mathrm{~s}^{-1}$ were recorded in the centre of the seagrass bed and averaged only half the values measured at the exposed area (Table 1). Mean water depth at both seagrass sites varied from 0.7 to $1 \mathrm{~m}$ at high tide. The seagrasses in the exposed seagrass site were covered by epiphytes as a consequence of stronger currents, promoting fouling on seagrass leaves by reducing the density of grazers (Schanz et al. 2002).

Seagrass stands. To compare both seagrass sites, extent, biomass and plant morphology of Zostera noltii were estimated at times with highest seagrass density in August and September from 1997 to 1999. Density of Z. noltii was recorded in 1997 and 1999.

The extents of seagrass stands were recorded twice in summer 1999, by pacing off the edges of the seagrass beds and determining the position every $3 \mathrm{~s}$ using a Global Positioning System (GPS).

Aboveground and belowground biomass was estimated monthly by taking box cores of $100 \mathrm{~cm}^{2}$ $(n=6)$. Seagrass cores were washed to remove sedi- ment, adherent fauna and algae; shoots were separated from roots and rhizomes. When necessary, the seagrass leaves were cleaned of epiphytes using a scalpel. Ash-free dry weight (AFDW) was calculated as the difference in dry weight (DW) (2 to $5 \mathrm{~d}$ at $60^{\circ} \mathrm{C}$ ) and ashed weight (combusted $12 \mathrm{~h}$ at $500^{\circ} \mathrm{C}$ ). Shoot density was determined in summer in 6 replicate test areas using a frame $\left(625 \mathrm{~cm}^{2}\right)$, except for 1998. To compare plant morphology, 20 to 25 seagrass shoots were sampled monthly at both sites. The number of leaves per shoot was counted, and the length of shoots, as well as the length and width of leaves, was measured.

Transplantation of seagrass sections. To test whether hydrodynamics influence seagrass bed development and plant morphology, cross transplantation experiments of seagrasses were carried out at the end of July 1999. Four seagrass sods, comprising 1 replicate test area $\left(2000 \mathrm{~cm}^{2}\right)$, were taken from each site by carefully pushing a box corer $(22 \times 21.6 \mathrm{~cm}, 20 \mathrm{~cm}$ high) into the sediment without disturbing the leaves of the plants. Seagrass sods were kept in boxes and transported to the laboratory, where they were kept covered by a thin layer of seawater at a temperature of $15^{\circ} \mathrm{C}$ for $1 \mathrm{~d}$. Six replicate seagrass sections from each donor seagrass bed were exchanged with 6 seagrass sections from the other site. In addition, 4 replicate control areas were transplanted within each donor site. To prevent initial transplantation losses at the exposed seagrass site due to erosion processes, probably caused by higher current speeds, the freshly transplanted seagrass sections were covered by a $5 \mathrm{~mm}$ PVC gauze $\left(2000 \mathrm{~cm}^{2}\right)$, anchored by iron pegs, during

Table 1. Characteristics of the hydrodynamically different seagrass beds (mean $\pm 1 \mathrm{SE}$, pooled data of August and September from 1997 to 1999)

\begin{tabular}{|c|c|c|}
\hline & Exposed & Sheltered \\
\hline \multicolumn{3}{|l|}{ Sediments } \\
\hline Median grain size $(\mathrm{mm})^{\mathrm{a}}$ & $1.03( \pm 0.05)$ & $0.81( \pm 0.01)$ \\
\hline Sorting coefficient $[\varphi(\mathrm{phi})]^{\mathrm{b}}$ & $0.99( \pm 0.06)$ & $1.24( \pm 0.19)$ \\
\hline Currents $\left(\mathrm{m} \mathrm{s}^{-1}\right)$ & $0.26( \pm 0.01)$ & $0.08( \pm 0.01)$ \\
\hline \multicolumn{3}{|l|}{ Seagrass } \\
\hline Shoot density $\mathrm{m}^{-2}$ & $1.987( \pm 202)$ & $4.869( \pm 558)$ \\
\hline $\begin{array}{l}\text { Aboveground biomass } \\
\left(\mathrm{g} \mathrm{AFDW} \mathrm{m} \mathrm{m}^{-2}\right)\end{array}$ & $30.65( \pm 2.76)$ & $49.64( \pm 5.82)$ \\
\hline 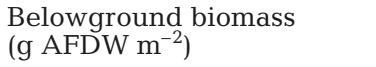 & $28.10( \pm 2.06)$ & $47.92( \pm 5.14)$ \\
\hline \multicolumn{3}{|l|}{ Plant morphology } \\
\hline Leaf number per shoot & $3.00( \pm 0.08)$ & $3.00( \pm 0.06)$ \\
\hline Shoot length (cm) & $10.72( \pm 0.35)$ & $16.18( \pm 0.49)$ \\
\hline Leaf length $(\mathrm{cm})$ & $7.02( \pm 0.21)$ & $10.46( \pm 0.30)$ \\
\hline Leaf width $(\mathrm{cm})$ & $0.09( \pm 0)$ & $0.09( \pm 0)$ \\
\hline \multicolumn{3}{|c|}{$\begin{array}{l}\text { a'Wentworth grade classification } \\
\text { bScale in Gray (1981) }\end{array}$} \\
\hline
\end{tabular}


the first day. Previous control transplantations within the donor sites revealed no transplantation effects on seagrass density and morphology.

The density and morphology of Zostera noltii shoots were monitored within the transplanted seagrass sections and in both control areas after 6 wk. To analyse the shoot morphology, 10 seagrass shoots were randomly sampled at each replicate seagrass section, and the number of leaves per shoot was counted. Furthermore, the length of shoots and the length and width of the associated leaves were determined as mentioned above.

Enclosure experiments. To test the influence of reduced tidal current velocities at the exposed seagrass site, enclosure experiments were carried out at the end of August 1999. Cages (PVC frames, $11.8 \mathrm{~cm}$ in diameter, $10 \mathrm{~cm}$ height, $1 \mathrm{~mm}$ mesh size) were placed on exposed seagrasses, as well as on sheltered seagrass sections freshly transplanted into the exposed area. After an experimental period of $4 \mathrm{wk}$, leaf length and leaf width of seagrasses were measured within the enclosures, as well as within the donor sites.

Flume experiment. By using an in situ 'three-current flume' (Schanz et al. 2002), the direct impact of modified current velocities on seagrass bed architecture was quantified experimentally under the same habitat conditions. The flume consisted of a heavy steel frame with flexible walls of textile awning $(7 \mathrm{~m}$ long, $12 \mathrm{~m}$ wide, $1 \mathrm{~m}$ high) forming 9 lanes. At the beginning of April 1999 the flume was placed into the Zostera noltii bed with a moderate ambient current regime and aligned with the prevailing flow direction, allowing for a bi-directional current regime. By modifying the channel openings the system either increased $\left(0.13 \pm 0.02 \mathrm{~m} \mathrm{~s}^{-1}\right)$, not notably altered $(0.08$ $\left.\pm 0 \mathrm{~m} \mathrm{~s}^{-1}\right)$ or reduced $\left(0.04 \pm 0.01 \mathrm{~m} \mathrm{~s}^{-1}\right)$ mean tidal currents in the mid-section of the flume relative to ambient mean current velocities outside the flume $(0.10 \pm 0.01)$ (Schanz et al. 2002). Each flow treatment consisted of 3 replicates. Mean current velocities were recorded in the central section of the different lanes, about $10 \mathrm{~cm}$ above the sediment surface by using an induction current meter (Marsh MCBirney). Mean current velocities were monitored 12 times during the beginning of both flood and ebb tide for half an hour about every 3 min, from April to October 1999, during calm weather.

Density of seagrasses and seagrass shoot morphology (number of leaves per shoot, shoot length, and the length and width of seagrass leaves) within the different lanes of the flume were recorded once in August and September 1999. As a control, seagrass development outside the flume was determined simultaneously (as mentioned above).

In addition, the grain-size distribution was analysed once at the end of the experiment by taking core samples (each $\sim 60 \mathrm{~g}$ ) in each of the lanes ( $\mathrm{n}=9$ per flow treatment) and using the standard dry sieving method (mesh series: 2 to $0.063 \mathrm{~mm}$ ).

Statistical analysis. All results were presented either as arithmetic or geometric means $( \pm \mathrm{SE})$. If variables were log-normally distributed, data were log-transformed prior to analysis, and back-transformed means were used as a central measure. Corresponding standard errors were calculated according to Mood et al. (1974). Differences between sites and experimental effects were analysed by means of analysis of variance (ANOVA), followed by Tukey's honest-significantdifferences (HSD) multiple-comparison test. Data were previously tested for homoscedasticity of variances by using Cochran's test to fulfil the assumptions of ANOVA. Differences were considered to be statistically significant if $p$-values were $<0.05$. All statistical tests were carried out using the STATISTICA programme (StatSoft).

\section{RESULTS}

\section{Comparison of seagrass stands}

Zostera noltii stands occurred at both locations during the study period, but the extent of the sheltered seagrass bed $\left(546013 \mathrm{~m}^{2}\right)$ exceeded that of the exposed stand $\left(12525 \mathrm{~m}^{2}\right)$ by $>40$-fold.

The mean density of seagrass shoots at the sheltered site was slightly higher than that at the exposed site in 1997, but reached almost the 3-fold value in 1999 (Fig. 2, Tables $1 \&$ 2; pooled data of August and September each year). The mean biomass of sheltered seagrasses increased slightly in 1997, but exceeded the exposed seagrass biomass by almost $65 \%$ in 1998, and was twice as high in 1999 (Fig. 2, Tables 1 \& 2; pooled data of August and September each year). Although the aboveground biomass, as well as the belowground biomass, of sheltered seagrasses was almost twice as high compared to the biomass in the exposed area (Tables $1 \& 2$; pooled data of August and September each year), there was no difference in the leaf/rhizome ratio between seagrass stands during the study period (ANOVA, $F=0.223, \mathrm{df}=1, \mathrm{p}=0.646$ ).

The mean length of shoots and the length of leaves were distinctly higher at the sheltered seagrass site than at the exposed area during the whole study (Fig. 2, Tables $1 \& 2$; pooled data of August and September each year). The width of sheltered seagrass leaves was slightly greater than the width of exposed seagrass leaves in 1997, whereas in 1999 the width of exposed leaves slightly exceeded that of the sheltered seagrasses (Table 2; pooled data of August and Sep- 
tember each year). No difference in leaf width between both seagrass sites was observed in 1998 (Table 2).

The number of seagrass leaves per shoot did not differ among exposed and sheltered seagrasses from 1997 to 1999 (Tables 1 \& 2; pooled data of August and September each year).

\section{Transplanted seagrasses}

All seagrass sods were established successfully, and no losses of seagrass shoots were observed at either site $1 \mathrm{~d}$ after transplantation. After transplantation of sheltered seagrasses into the exposed stand, some seagrass plants temporarily changed their colour from green to red-brown. After $6 \mathrm{wk}$, the initial high number of transplanted, sheltered seagrass shoots was reduced by $77 \%$, and had diminished to the same density as the surrounding exposed seagrass bed (Tukey's test, $p=0.72$ ) (Fig. 3A, Table 3). The initial number of leaves per shoot decreased by $25 \%$ after transplantation (Fig. 4A, Table 3). The length of shoots was reduced by $70 \%$, and the length of leaves by $71 \%$ of the initial length values (Fig. 4A, Table 3). Even the width of transplanted leaves decreased by $30 \%$ of the initial value within $6 \mathrm{wk}$. After 6 wk these plant morphological characteristics showed an even stronger reduction within the transplants than these same parameters showed in the ambient, exposed seagrasses (leaf number per shoot: Tukey's test, $\mathrm{p}<0.001$; leaf length: Tukey's test, $\mathrm{p}<0.0001$; leaf width: Tukey's test, $\mathrm{p}<0.0001$ ) (Fig. 4A).

After transplantation of seagrass sections from exposed into the sheltered seagrass stand the initial shoot number increased nearly 2 -fold and reached almost the same value of the surrounding sheltered seagrasses within 6 wk (Fig. 3B, Table 3). The initial shoot length increased by $29 \%$, and the length of leaves increased by almost $40 \%$ within the trans-
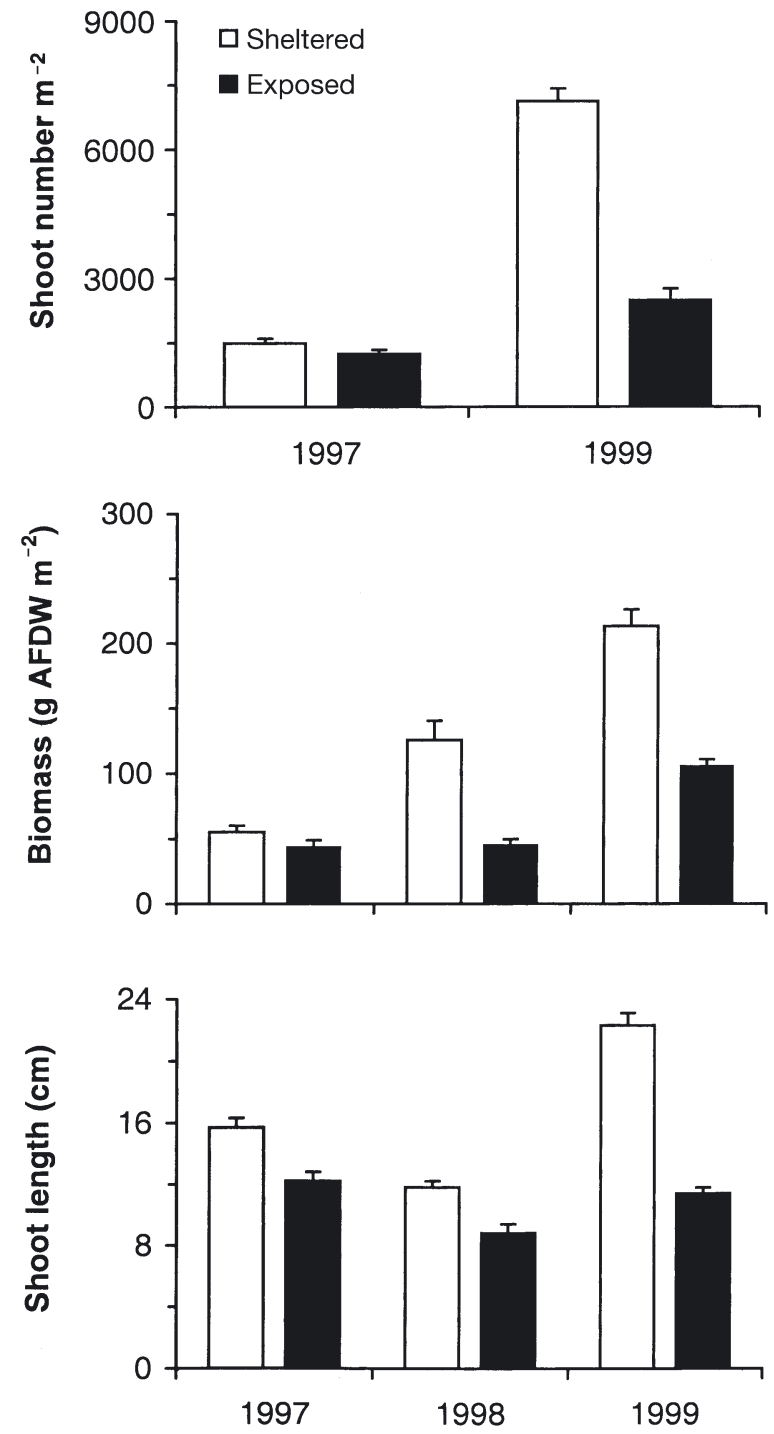

Fig. 2. Comparison of the hydrodynamically exposed and sheltered Zostera noltii stands from 1997 to 1999. Density ( $\mathrm{n}=$ $18)$, biomass $(n=12)$ and shoot length $(n=50)$ (means \pm SE) of sheltered seagrasses were distinctly higher than in exposed seagrass bed

Table 2. F-values and significance levels (p) of ANOVA for differences between the seagrass beds with different hydrodynamic exposure describing the conditions during the investigation period in August and September from 1997 to 1999 (pooled data). -: data missing

\begin{tabular}{|c|c|c|c|c|c|c|c|c|c|c|c|c|}
\hline \multirow[b]{2}{*}{ Parameter } & \multirow[b]{2}{*}{$\mathrm{df}$} & \multirow[b]{2}{*}{ MS } & \multirow[b]{2}{*}{$F$} & \multirow[b]{2}{*}{$\mathrm{p}$} & \multirow[b]{2}{*}{$\mathrm{df}$} & \multirow[b]{2}{*}{ MS } & \multirow{2}{*}{$\begin{array}{r}998- \\
F\end{array}$} & \multirow[b]{2}{*}{$\mathrm{p}$} & \multirow[b]{2}{*}{$\mathrm{df}$} & \multirow[b]{2}{*}{ MS } & \multirow{2}{*}{$\begin{array}{r}1999- \\
F\end{array}$} & \multirow[b]{2}{*}{$\mathrm{p}$} \\
\hline & & & & & & & & & & & & \\
\hline Biomass & 1 & 98.30 & 2.76 & ns & 1 & 5.30 & 39.13 & $<0.0001^{\mathrm{a}}$ & 1 & 2.80 & 84.62 & $<0.0001^{\mathrm{a}}$ \\
\hline Shoot density & 1 & 393300.53 & 0.56 & $\mathrm{~ns}$ & - & - & - & - & 1 & 11.48 & 79.14 & $<0.0001$ \\
\hline Leaf number per shoot & 1 & 0.02 & 0.27 & ns & 1 & 0.35 & 2.42 & $\mathrm{~ns}^{\mathrm{a}}$ & 1 & 0.05 & 0.10 & $\mathrm{~ns}^{\mathrm{a}}$ \\
\hline Shoot length & 1 & 312.23 & 17.71 & $<0.0001$ & 1 & 229.52 & 18.53 & $<0.0001$ & 1 & 8.34 & 154.44 & $<0.0001^{\mathrm{a}}$ \\
\hline Leaf length & 1 & 14.32 & 20.74 & $<0.0001^{\mathrm{a}}$ & 1 & 193.61 & 17.09 & $<0.0001$ & 1 & 30.64 & 94.97 & $<0.0001^{\mathrm{a}}$ \\
\hline Leaf width & 1 & 0.00 & 8.59 & $<0.01^{\mathrm{a}}$ & 1 & 0.00 & 0.13 & ns & 1 & 0.00 & 5.28 & $<0.05^{\mathrm{a}}$ \\
\hline
\end{tabular}



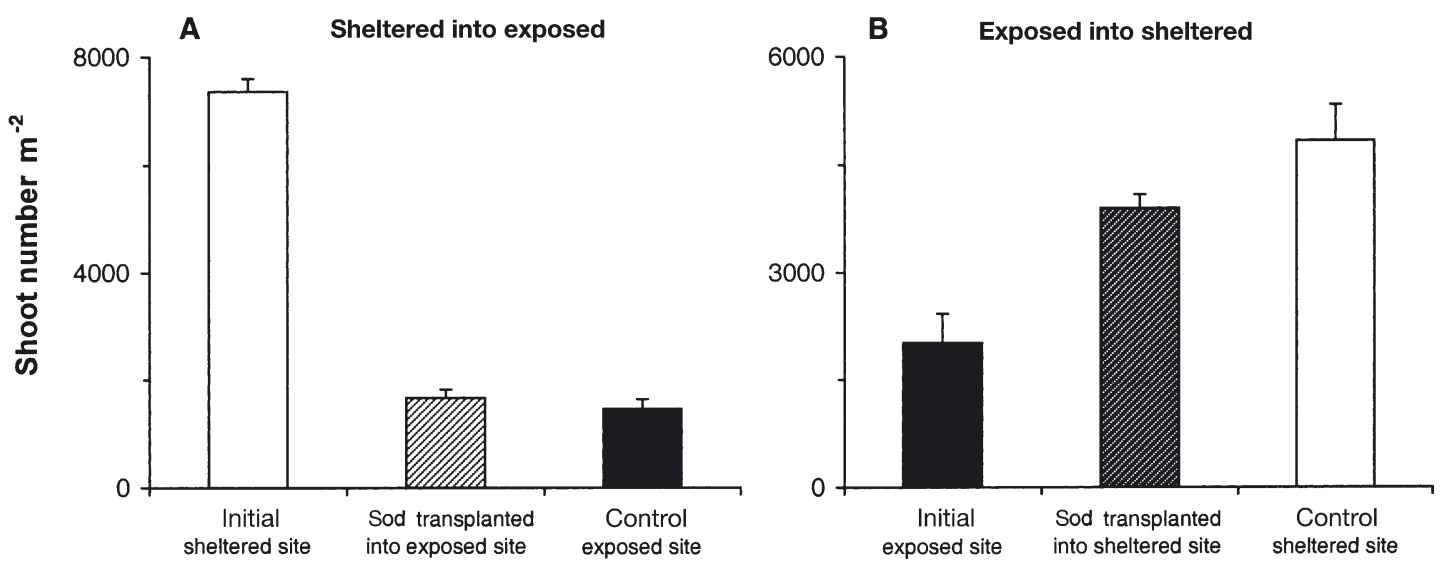

Fig. 3. Transplantation effect on seagrass density after $6 \mathrm{wk}$. (A) Initial shoot number (mean $\pm \mathrm{SE}, \mathrm{n}=6$ ) drastically decreased after transplantation of sheltered seagrasses into the exposed site. (B) Initial density of exposed seagrass shoots $($ mean $\pm S E, n=6)$ distinctly increased after transplantation into the sheltered site

plants (Fig. 4B \& Table 3). Seagrass transplants had significantly shorter shoots (Tukey's test, $\mathrm{p}<0.05$ ) and leaves (Tukey's test, $\mathrm{p}<0.001$ ) than the surrounding sheltered seagrasses after $6 \mathrm{wk}$. There were no differences in the leaf width or in the number of leaves per shoot between initial values and seagrass sections transplanted from exposed into the sheltered seagrass bed (Fig. 4B, Table 3). However, the leaf width of transplanted, exposed seagrasses significantly exceeded that of the surrounding sheltered seagrasses by $10 \%$ after 6 wk (Tukey's test, $\mathrm{p}<0.0001$ ) (Fig. 4B).

\section{Enclosed seagrasses}

Table 3. Split-plot ANOVA for effects of transplantation and enclosure experiments on the seagrass density and shoot morphology (number of leaves per shoot, shoot length, leaf length and leaf width)

\begin{tabular}{|c|c|c|c|c|}
\hline Treatment & $\mathrm{df}$ & MS & $F$ & $\mathrm{p}$ \\
\hline \multicolumn{5}{|l|}{ Transplantations } \\
\hline \multicolumn{5}{|l|}{ Sheltered into exposed } \\
\hline Shoot density & 2 & 67162792 & 298.61 & $<0.0001$ \\
\hline Leaf number per shoot & 2 & 5.733 & 16.28 & $<0.0001$ \\
\hline Shoot length ${ }^{\mathrm{a}}$ & 2 & 8.559 & 159.80 & $<0.0001$ \\
\hline Leaf length ${ }^{a}$ & 2 & 29.757 & 109.50 & $<0.0001$ \\
\hline Leaf width ${ }^{a}$ & 2 & 0.023 & 87 & $<0.0001$ \\
\hline \multicolumn{5}{|l|}{ Exposed into sheltered } \\
\hline Shoot density & 2 & 12335332 & 13.83 & $<0.001$ \\
\hline Leaf number per shoot & 2 & 0.128 & 1.57 & $\mathrm{~ns}$ \\
\hline Shoot length ${ }^{\mathrm{a}}$ & 2 & 1.088 & 32.43 & $<0.0001$ \\
\hline Leaf length ${ }^{\mathrm{a}}$ & 2 & 7.473 & 32.93 & $<0.0001$ \\
\hline Leaf width ${ }^{\mathrm{a}}$ & 2 & 0.002 & 104.54 & $<0.0001$ \\
\hline \multicolumn{5}{|l|}{ Enclosures } \\
\hline Leaf length ${ }^{\mathrm{a}}$ & 2 & 0.003 & 80.68 & $<0.0001$ \\
\hline Leaf width ${ }^{\mathrm{a}}$ & 2 & 0.002 & 135.68 & $<0.0001$ \\
\hline \multicolumn{5}{|c|}{ 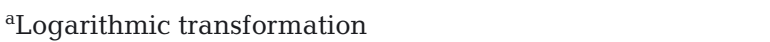 } \\
\hline
\end{tabular}

The enclosures significantly increased the length and width of seagrass leaves within the exposed seagrass stand (Fig. 5, Table 3). Both the enclosed, exposed seagrasses and the enclosed seagrasses transplanted from the sheltered into the exposed site produced distinctly longer and wider leaves than ambient seagrasses without cages within 6 wk (Fig. 5, Table 3). Surprisingly, the leaf length of all 'caged' seagrasses at the exposed seagrass site became as long as seagrass leaves in the sheltered stand within $6 \mathrm{wk}$ (ANOVA, $F=1.157, \mathrm{df}=1, \mathrm{p}=$ 0.284 , pooled data of enclosures). However, the leaf widths within both enclosure treatments were slightly greater than the leaf widths of seagrasses in the sheltered area after the experimental period (ANOVA, $F=$ $80.68, \mathrm{df}=1, \mathrm{p}<0.0001$, pooled data of enclosures).

\section{Flume experiment}

The flume experiments showed no differences in the grain size distribution of the sediments within the lanes of different current flow (ANOVA, $F=0.486, \mathrm{df}=2, \mathrm{p}=$ $0.624)$. The sediment consisted of medium and very well sorted sand.

The density, the shoot length and the leaf length of Zostera noltii decreased with increasing currents (Fig. 6, Table 4; pooled data of August and September). The shoot number decreased by $21 \%$ from the lane with the lowest to the lane with mean flow rates, and was further reduced by $28 \%$ between lanes of mean and highest current velocities (Fig. 6, Table 4; pooled data of August and September) (Tukey's test, $\mathrm{p}<0.05$ between lanes of highest and lowest currents). Length of shoots decreased only slightly from reduced to mean current flow (Tukey's test, $\mathrm{p}=0.34$ ), but was reduced 
A Sheltered into exposed
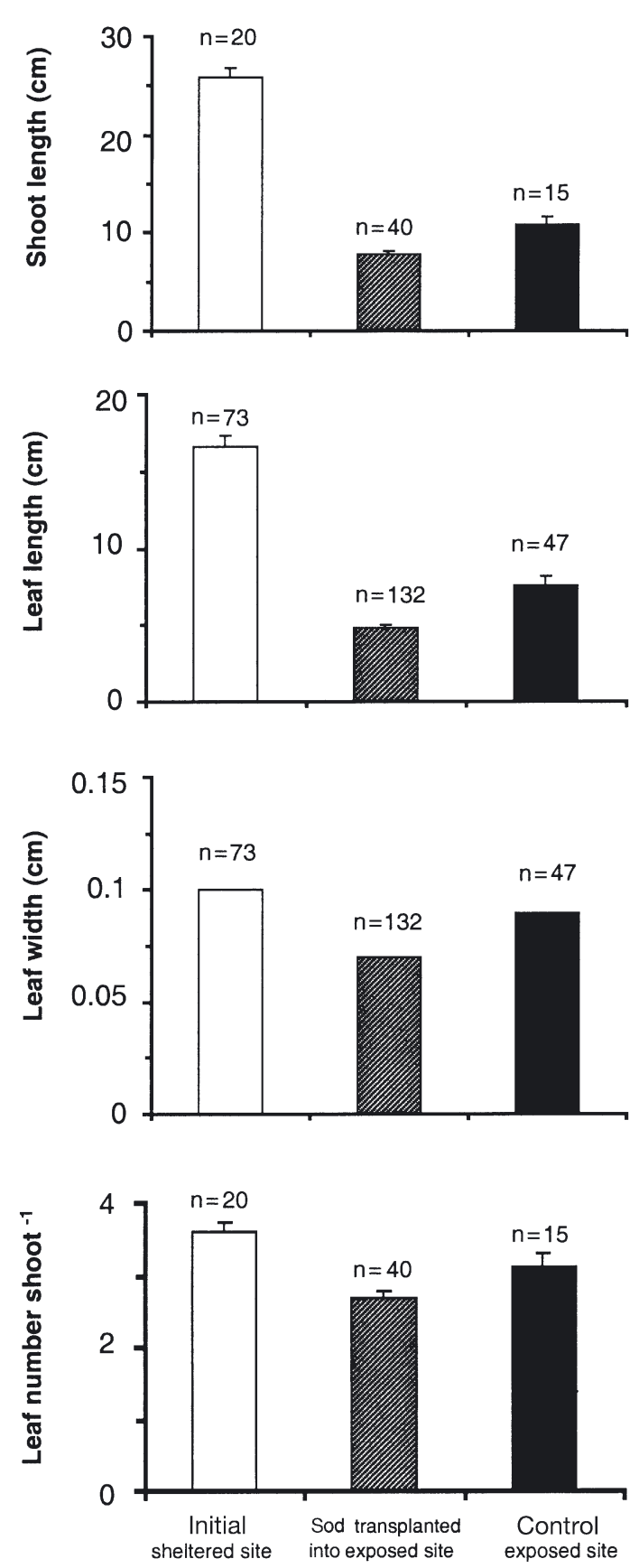

B Exposed into sheltered
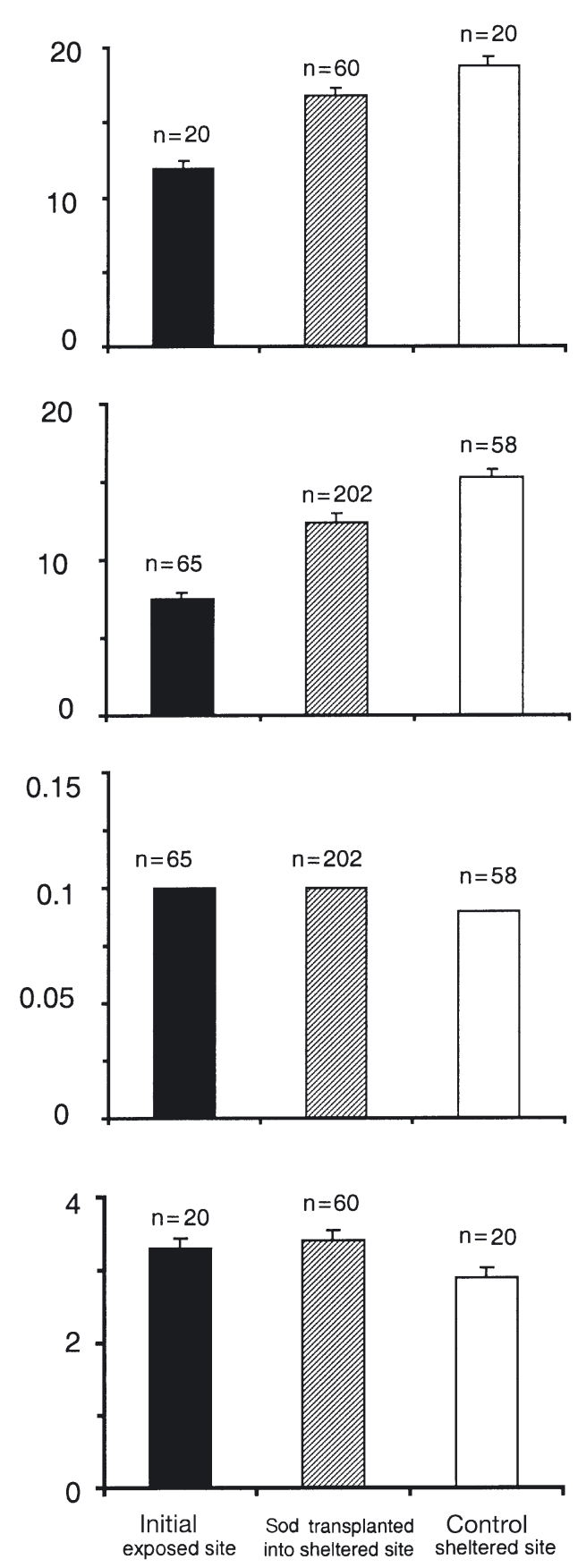

Fig. 4. (A,B) Transplantation effect on seagrass plant morphology after 6 wk. (A) Initial length of shoots, length and width of leaves, and the leaf number per shoot significantly decreased after transplantation of sheltered seagrasses into the exposed site (mean \pm SE). (B) Initial shoot length and leaf length significantly increased after transplantation of exposed seagrasses into the sheltered site, whereas no changes could be observed in leaf width and in the number of leaves per shoot (mean \pm SE). Leaf

by $16 \%$ between the lanes of mean and highest current velocities (Tukey's test, $\mathrm{p}<0.01$ ). The leaf length was reduced by nearly $10 \%$ from reduced to mean current flow (Tukey's test, $\mathrm{p}=0.28$ ) and decreased by $17 \%$ between lanes of mean and highest velocities (Fig. 6, Table 4; pooled data of August and September) (Tukey's test, $\mathrm{p}<0.001$ between lanes of highest and lowest currents). Leaf width and number of leaves per 

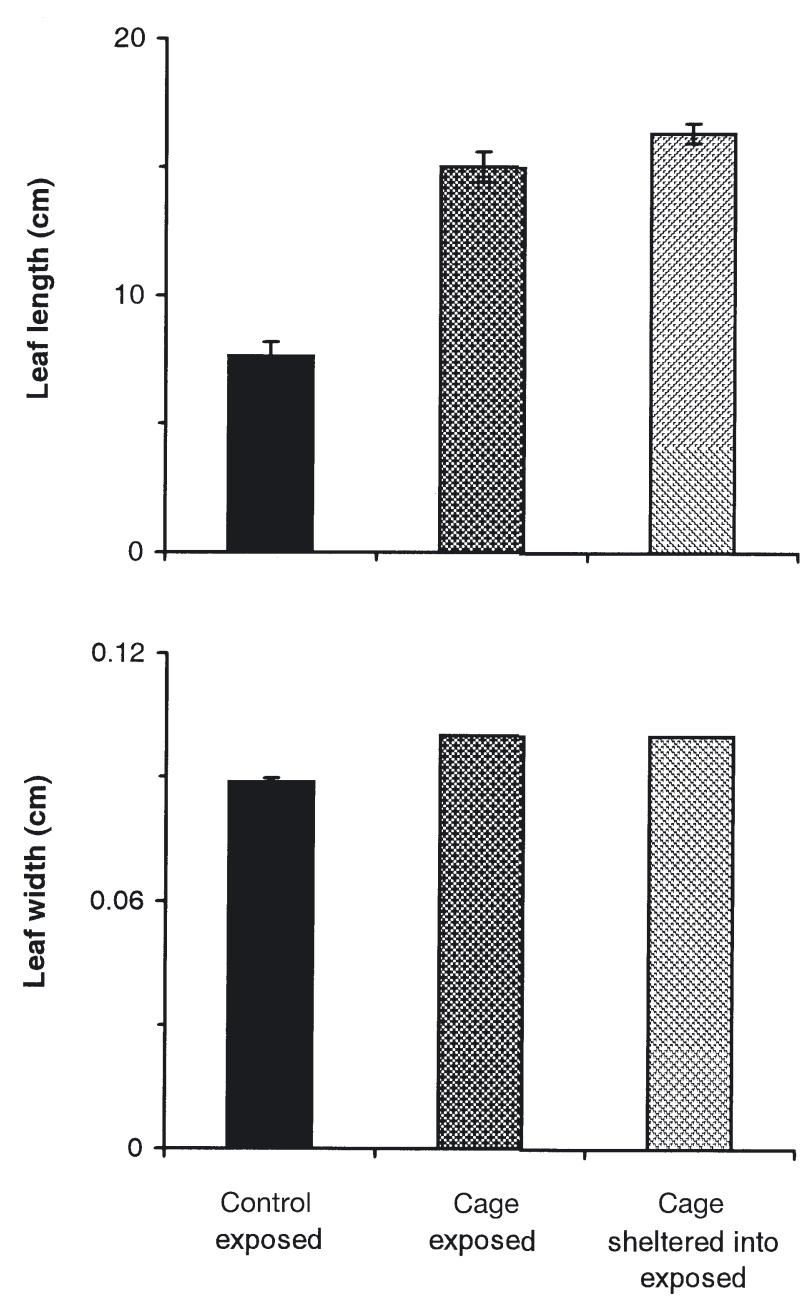

Fig. 5. Enclosure experiments in exposed seagrasses (exposed seagrasses with and without cages, and cages on seagrasses transplanted from sheltered into exposed site). Leaf length and width within the enclosures (widths $\mathrm{SE}=0$ ) distinctly increased after 6 wk (mean $\pm \mathrm{SE}, \mathrm{n}=50)$

shoot did not differ between seagrasses within the flume and the ambient seagrasses outside (Table 4; pooled data of August and September).

\section{DISCUSSION \\ Direct impact of stronger hydrodynamics on seagrasses}

The comparison of different seagrass sites in the Sylt-Rømø Bight indicates that hydrodynamics may impact intertidal seagrass characteristics at the population level (extent, biomass and density) as well as on the individual level (leaf number per shoot, shoot and leaf length). All seagrass characteristics recorded from 1997 to 1999 (except the leaf width) were distinctly lower at the exposed site than in the sheltered area. Even the belowground biomass was almost half as high in exposed stands, in contrast to studies that found a tendency to larger belowground biomass in exposed versus sheltered areas (Kautsky 1987, Coops et al. 1991, Fonseca \& Bell 1998). The decrease in belowground biomass might be the consequence of decreasing nutrient concentrations within the sediments caused by intense water movements washing out sediment porewater (Koch 1999). Although a relation between higher water flow and the enhanced
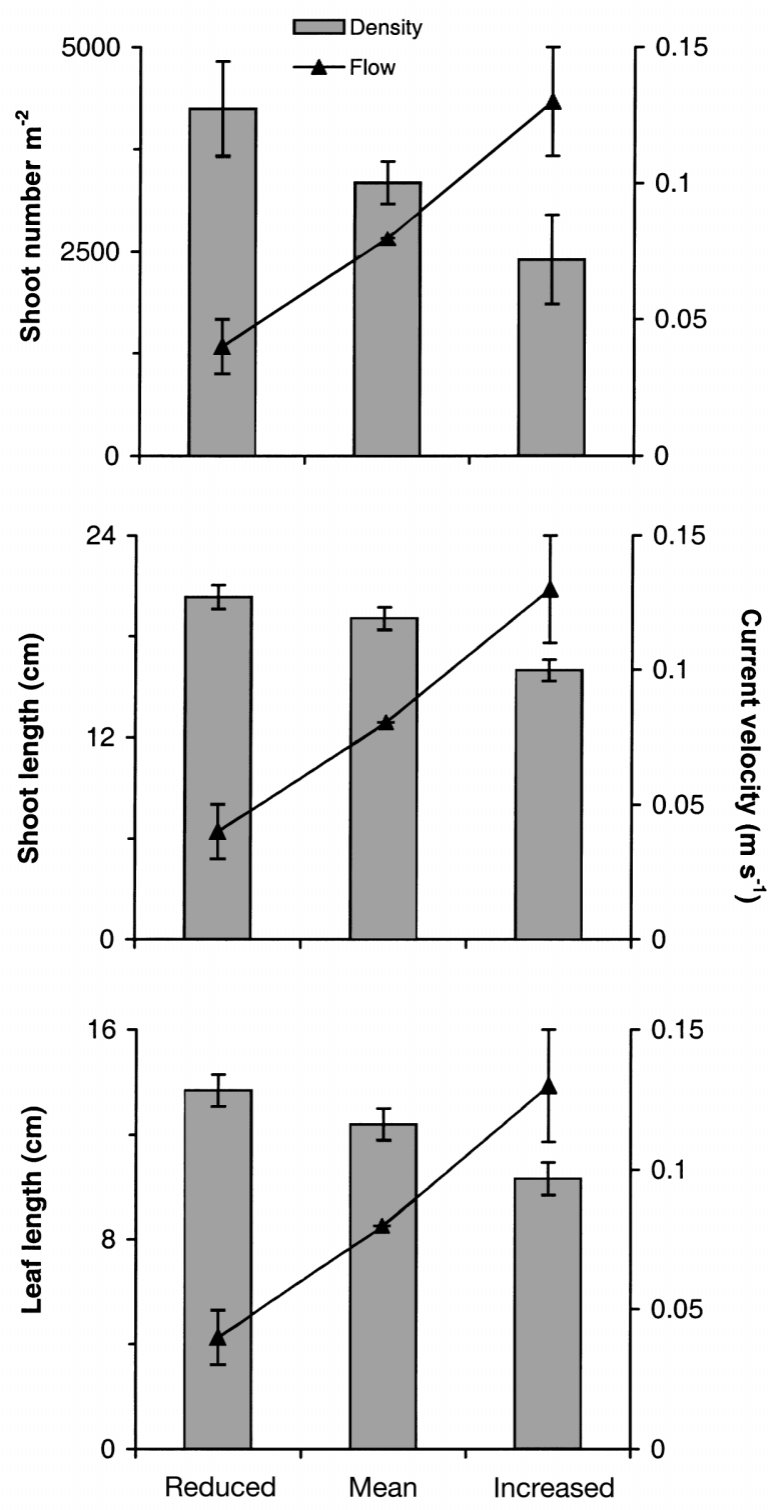

Fig. 6. Effects of reduced-, mean- and increased-flow treatments within the 'three-current flume'. Shoot number $(\mathrm{n}=6)$, shoot length $(n=42)$ and leaf length $(n=132)($ mean \pm SE) decreased with increasing current velocities 
Table 4. F-values and significance levels (p) of ANOVA for effects of the in situ flume experiment on seagrass density and shoot morphology (number of leaves per shoot, shoot length, leaf length and leaf width) within the 'three current-flume'

\begin{tabular}{|lcccc|}
\hline & df & MS & $F$ & $p$ \\
\hline Shoot density & 3 & 27791132 & 24.443 & $<0.0001$ \\
Leaf number per shoot & 3 & 0.397 & 0.904 & ns \\
Shoot length & 3 & 135.993 & 7.526 & $<0.001$ \\
Leaf length & 3 & 399.567 & 8.635 & $<0.0001$ \\
Leaf width & 3 & 0.002 & 1.191 & ns \\
& & & & \\
\hline
\end{tabular}

development of seagrass belowground biomass (which anchors the plants firmly and prevents the shoots from being washed away) is suspected (Cooper \& McRoy 1988, Peralta et al. 2000), no difference in the leaf/rhizome ratio between the sites was found in the present study. However, the lower values of the seagrass biomass and density, as well as the smaller differences between the study sites in 1997 compared to the following years, are presumably attributable to the effects of the severe winter in 1995/1996, initially causing a strong decline in many intertidal benthic populations, due to ice drift (driven by tidal currents and wind) (e.g. Günther \& Niesels 1999, Armonies et al. 2001).

The cross transplantation experiments revealed a negative impact of strong water dynamics, by drastically reducing the initial density and shoot morphology after transplanting sheltered seagrasses into the exposed site, thereby supporting the recorded seagrass pattern. In the Dutch Wadden Sea, van Katwijk \& Hermus (2000) consistently observed the complete loss of unprotected transplants after transplanting Zostera marina to a greater depth, where water dynamics were more severe. Stronger hydrodynamics trigger erosion processes which may detach roots and rhizomes from sediments, thereby thinning out seagrass stocks (Kirkman \& Kuo 1990). Severe damage to seagrass beds has also been reported due to wave action and/or sand abrasion after hurricanes (Birch \& Birch 1984, Poiner et al. 1989, Preen et al. 1995). Additionally, the decrease of seagrass leaf length in exposed areas might be caused by strong water dynamics (too low to remove whole plants), causing leaf loss, presumably due to increased leaf drag (van Katwijk \& Hermus 2000). However, shorter leaves have also been recorded to have developed as a morphological adaptation, being more robust to exposure and light (Cooper \& McRoy 1988). In contrast, after transplanting exposed seagrasses into the sheltered area, the initial seagrass density doubled and the length of shoots and leaves increased distinctly. Worm \& Reusch (2000) recorded an increased shoot growth in relation to higher initial shoot density in $Z$. marina patches, suspected to be linked to reduced current velocity (Fonseca et al. 1982), sediment stabilisation and physiological processes among shoots (Olesen \& Sand-Jensen 1994). In agreement with the findings of van Katwijk \& Hermus (2000), the enclosure experiments at the exposed seagrass bed (which artificially created a sheltered situation due to the gauze of the cages) led to an increase in the length and width of seagrass leaves within the enclosures, thereby supporting the results of the transplants within the sheltered sites. Additionally, these findings contribute to exclud other possible site-specific differences, e.g. changes in average water depth and differences in light availability and nutrients, thus supporting the indicated impact of hydrodynamics.

\section{Hydrodynamics versus biotic and abiotic factors}

Bioturbation (Philipart 1994, Valentine et al. 1994, Townsend \& Fonseca 1998) and burrowing of polychaetes and crabs (Davis et al. 1998, Hughes et al. 2000) has been shown to inhibit development and transplantation success of seagrasses. However, the effect of these processes on Zostera noltii transplants can be excluded, as higher abundances of adult lugworms Arenicola marina (Schanz unpubl. data) and crabs Carcinus meanas (Polte 2000, Schanz et al. 2000) were recorded in sheltered seagrass sites, where seagrasses are well developed.

Although epiphyte cover on seagrass leaves dominates at exposed seagrass sites, a decrease in seagrass development due to epiphyte shading (Neckles et al. 1993, Williams \& Ruckelshaus 1993) can also be excluded. Both the exposed seagrass covered by epiphytes and the transplanted sheltered seagrasses without visible epiphytes (but associated epiphyte-grazing snails) showed distinctly higher leaf values within the enclosures than in the ambient, exposed seagrasses without cages after $6 \mathrm{wk}$. Within the enclosures, artificial shading may have been caused by the gauze. In contrast, epiphyte cover on exposed seagrasses might have enhanced leaf drag due to the heavy load, thereby reducing leaf flexibility and leading to severance of plant parts (Jernakoff et al. 1996, Verduin \& Backhaus 2000). Consequently, it is assumed that the lower density and plant morphology at exposed seagrass sites may be at least partly influenced by epiphytes, which were indirectly influenced by strong hydrodynamics, which, in turn, reduce the density of grazers (Schanz et al. 2002).

The temporal change in leaf colour (into red-brown) after transplanting seagrasses into the exposed area presumably resulted from stress due to higher irradi- 
ance caused by the sparse seagrass cover (PérezLloréns \& Niel 1993). This is supported by brighter green leaves at the exposed area, compared to the darker green of sheltered leaves (Schanz pers. obs.) attributed to a higher concentration of photosynthetic pigments (Peralta et al. 2000). As the density of exposed seagrasses was too low to retain a water layer during low tide, as observed in dense, sheltered beds (Polte 2000), this may expose seagrasses to higher radiation and desiccation, and, in turn, might limit seagrass development in the upper tidal zone (Leuschner et al. 1998).

However, with the 'three-current flume', which altered the tidal currents within one seagrass stand, the possible impacts of the animal-plant interactions and radiation stress on the seagrass pattern could be separated from those caused by current velocities. This experiment clearly demonstrated the inverse relation between increasing tidal current velocities and seagrass development and morphology under the same habitat conditions (as changes of the environmental condition within the different lanes were not expected; even sediment composition remain unaltered).

In the northern Wadden Sea, seagrasses are generally distributed along the sheltered sides of the barrier islands, protected from stronger currents and waves. In accordance with recent studies of Fonseca \& Bell (1998) and van Katwijk \& Hermus (2000), changes in seagrass distribution are related to depth gradients at the study sites, attributed to increasing current velocities caused by deeper tidal channels within the SyltRømø Bight. In addition, hydrodynamics may also control the structural pattern of seagrass beds on a horizontal scale, as the extent and biomass of Zostera noltii beds increased with increasing distance from the deep tidal channel at the entrance of the bight, attributed to more moderate tidal current velocities deeper inside the bay (Schanz unpubl. data).

As hydrodynamics affect various processes in the seagrass system (Gerard \& Mann 1979, Wheeler 1980, Ackermann 1986, Fonseca \& Kenworthy 1987, Koehl \& Alberte 1988, Koch 1994), increasing hydrodynamics might contribute directly as well as indirectly to deterioration or even loss of seagrass beds. This raises the question whether a certain threshold exists between water dynamics and the development of seagrass beds. Conover $(1964,1968)$ and Fonseca \& Kenworthy (1987) reported that a current speed $>0.5 \mathrm{~m} \mathrm{~s}^{-1}$ is critical for the standing stock of subtidal Zostera marina, whereas Fonseca et al. (1983) estimated an upper limit of approximately 1.2 to $1.5 \mathrm{~m} \mathrm{~s}^{-1}$ velocity that $Z$. marina is able to tolerate. In our field experiments a significant reduction of shoot morphology and density of $Z$. noltii was observed at current velocities $>0.08 \mathrm{~m} \mathrm{~s}^{-1}$ within the 'three-current flume', whereas the maximum cur- rent speeds which $Z$. noltii is able to tolerate may be $>0.33 \mathrm{~m} \mathrm{~s}^{-1}$, as recorded at the exposed area. Once a seagrass bed has been severely damaged, e.g. by heavy storms, many years will pass before subsequent recovery has taken place (Patriquin 1975, Zieman 1976, Birch \& Birch 1984, Poiner et al. 1989, Williams 1990).

In the Wadden Sea, hydrodynamics changed dramatically during the last century, presumably attributed to coastal engineering and a rise in sea level (Führböter \& Jensen 1985, Hemminga \& Duarte 2000), and this has led to increasing erosion processes and drastic losses of shore biotopes (Asmus \& Asmus 1998, Reise et al. 1998). In agreement with de Jonge \& de Jong (1992), our findings may contribute to explaining the failure of re-establishment of seagrasses at sites where they once occurred as extended beds and where they were diminished due to the wasting disease in the early 1930s. However, since changes in environmental conditions are ongoing (rise in sea level, higher storm frequency), hydrodynamics have to be considered in future research as one of the driving forces controlling seagrass bed development.

Acknowledgements. Sincere thanks are especially given to I. Albath, J. Wolfram and P. Polte for their energetic assistance in the field. B. Hussel is thanked for recording the GPS data. We kindly acknowledge R. Asmus for critically reading the manuscript and B. Goeck (University of Port Elizabeth, South Africa), who provided help in correcting the English. Three anonymous reviewers are thanked for valuable comments on the manuscript.

\section{LITERATURE CITED}

Ackermann JD (1986) Mechanistic implications for pollination in the marine angiosperm Zostera marina. Aquat Bot 24:343-353

Ackermann JD (1997) Submarine pollination in the marine angiosperm Zostera marina (Zosteraceae). I. The influence of floral morphology on fluid flow. Am J Bot 84:1099-1109

Armonies W, Herre E, Sturm M (2001) Effects of the severe winter 1995/96 on the benthic macrofauna of the Wadden Sea and the coastal North Sea near the island Sylt. Helgol Mar Res 55:170-175

Asmus H, Asmus R (1998) The role of macrobenthic communities for sediment-water material exchange in the SyltRømø tidal basin. Senckenb Marit 29:111-119

Birch WR, Birch M (1984) Succession and pattern of tropical intertidal seagrasses in Cockle Bay, Queensland, Australia: a decade of observations. Aquat Bot 19:343-367

Borum J (1985) Development of epiphytic communities on eelgrass (Zostera marina) along a nutrient gradient in a Danish estuary. Mar Biol 87:211-218

Borum J (1996) Shallow waters and land/sea boundaries. In: Richardson K, Jørgensen BB (eds) Eutrophication in coastal marine ecosystems. American Geophysical Union, Washington

Bulthuis DA (1987) Effects of temperature on photosynthesis and growth of seagrasses. Aquat Bot 27:27-40 
Burkholder JM, Mason KM, Glaskow HB (1992) Watercolumn nitrate enrichment promotes decline of eelgrass Zostera marina: evidence from seasonal mesocosm experiments. Mar Ecol Prog Ser 81:163-178

Burkholder JM, Glaskow HB Jr, Cooke JE (1994) Comparative effects of water-column nitrate enrichment of eelgrass Zostera marina, shoalgrass Halodule wrightii, and widgeon grass Ruppia maritima. Mar Ecol Prog Ser 105: 121-138

Conover JT (1964) Environmental relationships of benthos in salt ponds (plant relationships). RI Grad Sch Oceanogr Tech Rep 3(2)

Conover JT (1968) The importance of natural diffusion gradients and transport of substances related to benthic plant metabolism. Bot Mar 11:1-9

Cooper LW, McRoy CP (1988) Anatomical adaptations to rocky substrate and surf exposure by the seagrass genus Phyllospadix. Aquat Bot 32:365-381

Coops H, Boeter R, Smith H (1991) Direct and indirect effects of waves attack on halophytes. Aquat Bot 41:333-352

Davis RC, Short FT, Burdick DM (1998) Quantifying the effect of green crab damage to eelgrass transplants. Restor Ecol 6:297-302

de Jonge VN, de Jong DJ (1992) Role of tide, light and fisheries in the decline of Zostera marina L. in the Dutch Wadden Sea. Neth Inst Sea Res Publ Ser 20:161-176

de Jonge VN, de Jong DJ, van Katwijk MM (2000) Policy plan and management measurements to restore eelgrass (Zostera marina L.) in the Dutch Wadden Sea. Helgol Mar Res 54:151-158

den Hartog (1970) The seagrasses of the world. Verhandlingen der Koninklijke Nederlandse Akademie van Wetenschappen Afd. Natuurkunde Tweede Reeks Deel 59 No. 1. North-Holland, Amsterdam

Fonseca MS, Bell SS (1998) Influence of physical setting on seagrass landscapes near Beaufort, North Carolina, USA. Mar Ecol Prog Ser 171:109-121

Fonseca MS, Cahalan JA (1992) Preliminary evaluation of wave attenuation by four species of seagrass. Estuar Coast Shelf Sci 35:565-576

Fonseca MS, Kenworthy J (1987) Effects of currents on photosynthesis and distribution of seagrasses. Aquat Bot 27: $59-78$

Fonseca MS, Fisher JS, Ziemann JC, Thayer GW (1982) Influence of the seagrass, Zostera marina L., on current flow. Estuar Coast Shelf Sci 15:367-380

Fonseca MS, Ziemann JC, Thayer GW, Fisher JS (1983) The role of current velocity in structuring eelgrass (Zostera marina L.) meadows. Estuar Coast Shelf Sci 17:367-380

Führböter A, Jensen J (1985) Säkularänderungen der mittleren Tidewasserstände in der Deutschen Bucht. Kueste 42:78-100

Gambi MC, Nowell AMR, Jumars PA (1990) Flume observations on flow dynamics in Zostera marina (eelgrass) beds. Mar Ecol Prog Ser 61:159-169

Gerard V, Mann KH (1979) Growth and production of Laminaria longicuris populations exposed to different intensities of water movement. J Phycol 15:33-41

Gray JS (1981) The ecology of marine sediments. An introduction to the structure and function of the benthic communities. Cambridge Studies in Modern Biology 2, Cambridge University Press, Cambridge

Günther CP, Niesel V (1999) Effects of the ice winter 1995/96. In: Dittman S (ed) The Wadden Sea ecosystem, stability, properties and mechanisms. Springer, Berlin, p 194-205

Harlin MM, Thorne-Miller B, Boothroyd JC (1982) Seagrasssediment dynamics of a flood-tidal delta in Rhode Island
(USA). Aquat Bot 14:127-138

Hemminga MA, Duarte CM (2000) Seagrass ecology. University Press, Cambridge, p 1-298

Hughes R G, Lloyd D, Ball L, Emson D (2000) The effect of the polychaete Nereis diversicolor on the distribution and transplanting success of Zostera noltii. Helgol Mar Res 54: 129-136

Jernakoff P, Brearley A, Nielsen J (1996) Factors affecting grazer-epiphyte interactions in temperate seagrass meadows. Oceanogr Mar Biol Annu Rev 34:109-162

Kamermans P, Hemminga MA, de Jong DJ (1999) Significance of salinity and silicon levels for growth of a formerly estuarine eelgrass (Zostera marina) population (Lake Grevelingen, the Netherlands). Mar Biol 133:527-539

Kautsky L (1987) Life-cycles of three populations of Potamogeton pectinatus L., of different degrees of wave exposure in the Asko area, northern Baltic proper. Aquat Bot 27: 177-186

Kirkman H, Kuo J (1990) Pattern and process in southern Western Australian seagrasses. Aquat Bot 37:367-382

Koch EW (1994) Hydrodynamics, diffusion-boundary layers and photosynthesis of the seagrass Thalassia testudinum and Cymodocea nodosa. Mar Biol 118:767-776

Koch EW (1996) Hydrodynamics of a shallow Thallasia testudinum bed in Florida, USA. In: Kuo J, Phillips RC, Walker DI, Kirkman H (eds) Seagrass biology: proceedings of an international workshop. The University of Western Australia, Perth, p 105-109

Koch EW (1999) Preliminary evidence on the interdependent effect of currents and porewater geochemistry on Thalassia testudinum Banks es König seedlings. Aquat Bot 63:95-102

Koch EW, Gust G (1999) Water flow in tide- and wave-dominated beds of seagrass Thalassia testudinum. Mar Ecol Prog Ser 184:63-72

Koehl MAR, Alberte RS (1988) Flow, flapping, and photosynthesis of macroalgae: functional consequences of undulate blade morphology. Mar Biol 99:435-444

Larkum AWD, McComb AJ, Shepherd SA (1989) Biology of seagrasses: a treatise of the biology of seagrasses with special reference to the Australian region. Elsevier, New York

Leuschner C, Landwehr S, Mehlig U (1998) Limitation of carbon assimilation of intertidal Zostera noltii and $Z$. marina by desiccation at low tide. Aquat Bot 62:171-176

Mood AM, Graybill FA, Boes DC (1974) Introductions of the theory of statistics. McGraw-Hill, Kogakusha

Neckles HA, Wetzel RL, Orth RJ (1993) Relative effects of nutrients enrichment and grazing on epiphyte-macrophyte (Zostera marina L.) dynamics. Oecologia 93: 285-295

Olesen B, Sand-Jensen K (1994) Demography of shallow eelgrass (Zostera marina) populations - shoot dynamics and biomass development. J Ecol 82:379-390

Orth RJ, Luckenbach M, Moore KA (1994) Seed dispersal in a marine macrophyte: implications for colonization and restoration. Ecology 75:1927-1939

Patriquin DG (1975) 'Migration' of blowouts in seagrass beds at Barbados and Carricou, West Indies and its ecological and geological applications. Aquat Bot 1:163-189

Peralta G, Pérez-Lloréns JL, Hernández I, Brun F, Vergara JJ, Bartual A, Gálvez CM, Garcia CM (2000) Morphological and physiological differences between two morphotypes of Zostera noltii Hornem. from the south-western Iberian Peninsula. Helgol Mar Res 54:80-86

Pérez-Lloréns JL, Niel FX (1993) Temperature and emergence effects on the net photosynthesis of two Zostera noltii Hornem. morphotypes. Hydrobiologia 254:53-64 
Phillipart CJM (1994) Interactions between Arenicola marina and Zostera noltii on a tidal flat in the Wadden Sea. Mar Ecol Prog Ser 111:251-257

Poiner IR, Walker DI, Coles RG (1989) Regional studiesSeagrasses of tropical Australia. In: Larkum AWD, McComb AJ, Shepherd SA (eds) Biology of seagrasses: a treatise on the biology of seagrasses with special reference to the Australian region. Elsevier, Amsterdam, p 279-303

Polte P (2000) Einfluß hydrodynamischer Exposition auf die Präferenz mobiler Epifauna für eulitorale Seegrashabitate im Sylter Wattenmeer. Diplomarbeit, University of Oldenburg, Germany

Preen AR, Lee Long WJ, Coles RG (1995) Flood and cyclone related loss, and partial recovery, of more than $1000 \mathrm{~km}^{2}$ of seagrass in Hervey Bay, Queensland, Australia. Aquat Bot 52:3-17

Reise K (1989) Coastal changes in a tidal backbarrier basin of the northern Wadden Sea: are tidal flats fading away? Senckenb Marit 29:121-127

Reise K, Herre E, Sturm M (1998) Historical changes in the benthos of the Wadden Sea around the island of Sylt in the North Sea. Helgol Meeresunters 43:417-433

Schanz A, Polte P, Asmus H, Asmus R (2000) Currents and turbulence as a top-down regulator in intertidal seagrass communities. Biol Mar Medit 7:278-281

Schanz A, Polte P, Asmus H (2002) Cascading effects of hydrodynamics on an epiphyte- grazer system in intertidal seagrass beds of the Wadden Sea. Mar Biol 141: $287-297$

Scoffin TP (1970) The trapping and binding of subtidal carbonate sediments by marine vegetation in Bimini Lagoon, Bahamas. J Sedim Petrol 40:249-273

Short FT, Burdick DM (1996) Quantifying seagrass habitat loss in relation to housing development and nitrogen loading in Waquoit Bay, Massachusetts. Estuaries 19: $730-739$

Short FT, Neckles HA (1999) The effect of global climate change on seagrasses. Aquat Bot 63:169-196

Thayer GW, Bjorndal KA, Ogden JC, Williams SL, Zieman JC (1984) Role of larger herbivores in seagrass communities. Estuaries 7:351-375

Editorial responsibility: Otto Kinne (Editor),

Oldendorf/Luhe, Germany
Townsend EC, Fonseca MS (1998) Bioturbation as a potential mechanism influencing spatial heterogeneity of North Carolina seagrass beds. Mar Ecol Prog Ser 169:123-132

Valentine JF, Heck KL, Haper P, Beck M (1994) Effects of bioturbation in controlling turtlegrass (Thalassia testudinum Bank ex Konig) abundance: evidence from filed enclosures and observations in the northern Gulf of Mexico. J Exp Mar Biol Ecol 178:181-192

van Katwijk MM, Hermus DCR (2000) Effects of water dynamics on Zostera marina: transplantation experiments in the intertidal Dutch Wadden Sea. Mar Ecol Prog Ser 208:107-118

van Katwijk MM, Schmitz GHW, Gasseling AP, van Avesaath PH (1999) Effects of salinity and nutrient load and their interactions on Zostera marina. Mar Ecol Prog Ser 190: 155-165

Verduin JJ (1996) In situ submarine pollination in Amphibolis antarctica and its relationship to hydrodynamics. In: Kuo J, Phillips RC, Walker DI, Kirkman H (eds) Seagrass biology: proceedings of an international workshop. University of Western Australia, Perth, p 123-128

Verduin JJ, Backhaus JO (2000) Dynamics of plant-flow interactions for the seagrass Amphibolis antarctica: field observations and model simulations. Estuar Coast Shelf Sci 50: 185-204

Wheeler WN (1980) Effect of boundary layer transport on the fixation of carbon by giant kelp Macrocystis pyrifera. Mar Biol 56:103-110

Williams AB, Ruckelshaus MH (1993) Effects of nitrogen availability and herbivory on eelgrass (Zostera marina) and epiphytes. Ecology 74:909-918

Williams SL (1990) Experimental studies of Caribbean seagrass development. Ecol Monogr 60:449-469

Worcester SE (1995) Effects of eelgrass beds on advection and turbulent mixing in low current and low shoot density environments. Mar Ecol Prog Ser 126:223-232

Worm B, Reusch TBH (2000) Do nutrient availability and plant density limit seagrass colonization in the Baltic Sea? Mar Ecol Prog Ser 200:159-166

Zieman JC (1976) The ecological effects of physical damage from motor boats on turtle grass beds in southern California. Aquat Bot 2:127-139

Submitted: October 2, 2002; Accepted: May 6, 2003

Proofs received from author(s): September 26, 2003 